\title{
The Role of The Internal Audit Management of Enterprise Risk Management
}

\begin{tabular}{|c|c|c|}
\hline \multicolumn{3}{|c|}{ Siwidyah Desi Lastianti, Endang Muryani, Mahrus Ali } \\
\hline & iil: siwi.dy@gmail. & \\
\hline $\begin{array}{c}\text { Accepted : } \\
\text { December, } 052017\end{array}$ & $\begin{array}{c}\text { Reviewed : } \\
\text { January, } 102018\end{array}$ & $\begin{array}{c}\text { Published : } \\
\text { March,30 2018 }\end{array}$ \\
\hline
\end{tabular}

\begin{abstract}
Purpose: The aim of the study to present the role of internal audit in the company.

Design/methodology/approach: Research conducted qualitative nature and focus on how the role of internal audit of the management of risk in the organization.
\end{abstract}

Findings: . There is a relationship that is so tightly between the internal audit and corporate management, internal audit which can increase the value and achieve its goals.

Research limitations/implications: The Internal Audit Management of Enterprise Risk Management.

Practical implications: The role of internal audit in the company is very important to control not only the financial sector but also other sectors that have been determined by the management Internal audit should also adjust its function, not only on financial issues, but other problems, associated with risk and improved control strategies..

Originality/value: Internal audit was originally only focused on accounting examination, this time the tests associated with risk.

Paper type: Conceptual paper

Keywords: Audit, Internal Audit, Risk, Risk Management

\section{INTRODUCTION}

The role of internal auditor in the risk management of the company with another company is different. This arises because of the complexity of the different risks. Role of Internal Audit in a company to the management of risks will change over time follow-ment developm complexity of risk management implemented in the company (Lestari,

The Role of The Internal Audit Management of Enterprise Risk Management

Siwidyah Desi Lastianti, Endang Muryani, Mahrus Ali 
2018). In a crunch-tiknya role of internal audit in risk management include (1) focus the work of internal audit on key risks and important, as diidentifikasioleh management, (2) audit process Risk Management throughout the organization, (3) provide assurance to the management of risk, (5) provide support and active involvement in the process of risk management, (6) facilitate the identification / risk assessment and line management education in risk management and internal control, (7) to coordinate risk reporting to the Board of Commissioners and Board of Directors, the Audit Committee and others. The audit by internal auditors on banking activities not only include internal control weaknesses, but also shortcomings of risk management systems. The internal auditor is a tool of Directors to ensure that all elements of the company have the same understanding about the risks (Karmudiandri, 2014).

Assessment of risk management in order to achieve success and achieve business objectives and financial performance of an organization remains a major concern against which to make a decision (LASTIANTI, 2015). And it is a space for the internal audit to conduct an investigation. Internal audit itself is a profession that is evolving from time to time with the evolving standards. Along with business development organizations, internal audit which was originally only focused on financial issues, internal audit at the present time also supports the management of the organization to achieve its objectives by utilizing existing resources efficiently and increase in business as well as the risk management process. In accordance with the assumption that the internal audit is not an enemy to the organization(Syaifudin, 2017).

Through a variety of literature review, this paper will be presented theoretical approach regarding the internal audit contribution to efficient risk management. The purpose of this paper is to highlight the role of internal audit in helping management to manage risk.

\section{METHODS}

To investigate and provide a deeper understanding of how the role of internal audit of the management of risk in the workplace. The method used was to analyze and review the literature and standards both nationally and internationally issued to regulate the internal audit activity. Research conducted qualitative nature and focus on how the role of internal audit of the management of risk in the organization.

The paper is structured as follows. In the first part outlines the theoretical background needed on the concept of internal audit. Then will describe the concept of risk and risk management. In the next section will discuss the relationship between the internal audit and risk management in the organization. The last part is the conclusion of an outline of the research, as well as revealing the limitations of this study and suggestions for future research.

\footnotetext{
The Role of The Internal Audit Management of Enterprise Risk Management
}

Siwidyah Desi Lastianti, Endang Muryani, Mahrus Ali 


\section{DISCUSSION}

\section{A. The concept of Internal Audit}

in the company or organization, internal audit is within the department, together with other departments. With the development work in the field, the function of internal audit department develop not only related to financial issues, but covers all types of audits, such as operational audits, compliance audits, risk assessment, and so on.

It is important to give a sense of internal audit in order to make a major contribution to the business environment in which internal audit is located. An indication of the importance of the internal audit is the number of internal audit definition given by various researchers.

Audit comes from the Latin "aud tus" means listening (Hebeish, 2016), which emphasizes that the main function of the auditor is to do more listening dibadingkan speak. As a consequence, the auditor should have the skills or expertise to listen to good.

Auditing is a systematic process to acquire, evaluate the information and discernment objectively to ascertain the level of their compliance with the criteria set, and communicate the results to interested users. (American Accounting Association).

Based on the Institute of Internal Auditing (IIA, 1991; Taylor and Glezen, 1991; Konrath, 1996 cited by Karagiorgos, George, and Michail, 2007), internal auditing is"anindependent appraisal function, established within an organization to examine and Evaluate its activities as a service to theorganization."In

June 1999, The USA Institute of internal auditing (IIA), was officially given a new definition of the internal audit function as follows:"internal auditing is an independent, objective assurance and consulting activity designed to add value and improve an organization's operations. It helps an organization Accomplish its objectives by bringing a systematic, disciplined approach to Evaluate and improve the effectiveness of risk management, control, and governance processes."(Underlined by the author). The Charter Institute of Internal Auditors in the United Kingdom (UK) describes the role of internal auditors as follows:"Therole of internal audit is to provide independent assurance that an organization's risk management, governance and internal control processes are operating Effectively."

Internal audit role is to reviewing, especially to improve the activity and service entities, which leads to the strict policies and procedures made by each entity and is not limited to the financial aspect (Jinga C., 2009, page 54 quoted by Daniela and Tamas, 2013). Boulescu, M (2003) explains the definition of internal auditing as:

- an ongoing review of the economic activity of the entity;

- an independent appraisal activity, for the management of the entity, by checking the financial, accounting, and other operations, as the overall service to the entity;

- a job assessment, compliance records, records of assets, capital and the result is

- an attestation or certification of financial documents and accounting.

The Role of The Internal Audit Management of Enterprise Risk Management

Siwidyah Desi Lastianti, Endang Muryani, Mahrus Ali 
Based on the understanding and role of internal auditor given by various researchers, it can be concluded that the internal audit is an ongoing process, which is designed to add value to an organization, through a systematic approach to evaluate and develop the effectiveness of risk management, control and governance organization.

The main characteristics of internal audit is the independence and objectivity of the auditor who has an important impact on the effectiveness of internal control. Require management to disclose significant internal control deficiencies. At another level, the internal auditor is required to give an opinion that is objective, relevant, and trustworthy on management's assessment. Internal audit can be considered the standard for measuring the effectiveness of the management and board of directors in corporate governance (Caratas, 2014).

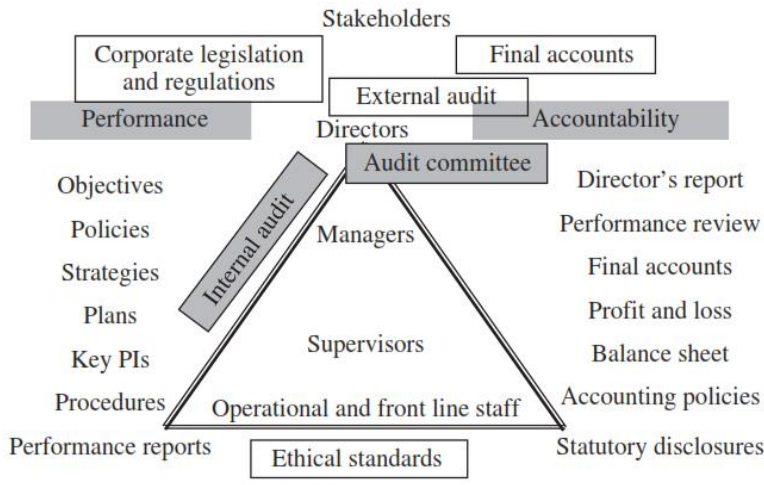

Figure 1- presents how the internal auditor position within the company.

Source: Pickett KHS, 2010.

Working together with the board of directors, audit committee and the risk committee, internal audit seemed like the only function in the organization who has a deep understanding of risk. Internal audit function needs differ from one company to another company, depending on the scale, diversity and complexity of the activities of the company and of the workforce, and the consideration of cost / benefit.

Internal audit is something simple, rapidly changing profession with high standards. Internal audits requires a deep understanding of the culture, policies, and procedures of the organization. They pay attention to efficiency and effectiveness and make recommendations for improvements to the organization when it was discovered discrepancies. Internal auditors assess risks to ensure that the control system is already strong organization. They evaluate the process and determine what works and what does not. The main task of the internal auditor function is to assist management and directors to achieve the goals and objectives of the organization.

The Role of The Internal Audit Management of Enterprise Risk Management

Siwidyah Desi Lastianti, Endang Muryani, Mahrus Ali 


\section{B. Development of Audit Internal}

Internalaudit as a profession, has been recognized since many years and always follow the changing needs of the entity. If at first the internal audit focused on the problems of accounting, internal audit is now oriented towards the detection of the main risks of the entity and the evaluation of the activity of the entity (Munteanu, 2013). Riskoriented approach has been a constant thing done by internal audit (Stanciu, 2016).

Based on the results of the audit of internal development, it can be concluded that the internal audit, from time to time, showing a trend of change as shown in Table 1.

Table 1- Brief Historical Development of Internal Auditing

\begin{tabular}{|l|c|}
\hline 1. Checking the accounting records & 1950 \\
\hline 2. Evaluation of conformity & 1960 \\
\hline 3. Examination of procedures & 1970 \\
\hline 4. Evaluation of controls & 1980 \\
\hline 5. Report on the internal control system & 1990 \\
\hline 6. Evaluation of the risk management system & 2000 \\
\hline 7. Improvement of the risk management system & 2001 \\
\hline 8. Reporting the activity performed & 2002 \\
\hline 9. Adding a value plus & 2003 \\
\hline 10. Consolidation of the internal audit & $2004 / 2009$ \\
\hline 11. Capacity of managing financial risk & $2010 / 2013$ \\
\hline
\end{tabular}

Source: Munteanu, 2013.

At first, the internal audit task only audit the accounting records, but there is a change from year to year, which is not only accounting issues are the focus of internal audit, evaluation of conformity, inspection procedures, control evaluation, a report on the system internal control, evaluation of the risk management system, improvement of risk management systems, reporting activities carried out, providing added value to the company, the internal audit consolidation and management of financial risk.

Recent international studies emphasize internal auditors need to turn their attention to the risks resulting from rapid technological developments (Stanciu, 2016). The basis of the system of internal audit is in respect of the risk assessment. Internal auditors should be able to manage any changes at all levels, especially those with risk berhubuungan (Caratas and Spatariu, 2014).

\section{Concept of Risk}

The word 'risk' is derived from the Italian, meaning 'brave'. In the sense of risk means an option. Risks arise from uncertainty and control based on the reduction of these uncertainties which are both possible and necessary. Risk can affect the organization both in the short, medium and long term. Such risks associated with operations, tactics and strategies. The strategy sets long-term goals of the organization, and strategic planning for an organization to be aged 3 years, 5 years, or more. Tactics determine how the organization intends to achieve the change. Therefore, tactical risk normally associated with the project, mergers, acquisitions, and product development.

\section{The Role of The Internal Audit Management of Enterprise Risk Management Siwidyah Desi Lastianti, Endang Muryani, Mahrus Ali}


Many definitions of risk given by various researchers. Pickett HM Treasury in 2010, defines risk as the uncertainty of the results in the timeframe arise from a combination of impact and probability of occurrence of potential. The Institute of Internal Audit defines risk as the uncertainty arising which has an impact on the achievement of objectives. Risk is measured in terms of consequences and likelihood.

In the ISO Guide 73 risk is the effect of uncertainty on objectives. The effects can be positive, negative, or deviation from the expected, and the risk is often described in terms of events, environmental changes or consequences. Australian Government states that the risk can be seen as a combination of the possibility that something could happen and the extent of damage or loss that may occur when this happens. Adverse events in the organization due to the development of various risk events both from within and from outside the organization (Figure 1.2).

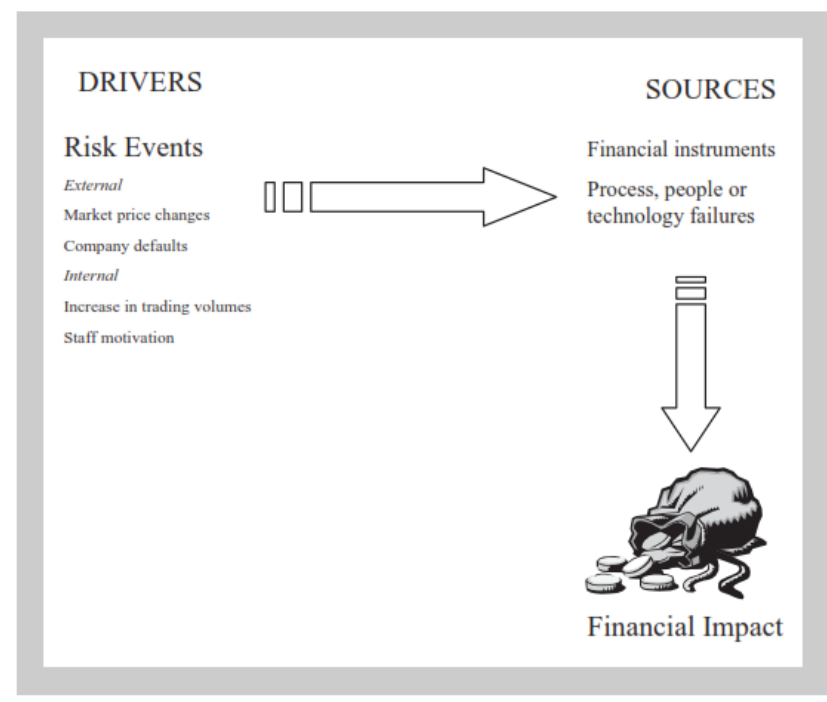

Figure 2- Sources and Drivers Risk in Organizations

Source: Gorrod, 2004.

mitigation and risk reduction usually focus on the source of risk, because the source of the risk comes from within the organization, then it can be controlled. While good risk management focus on the source and the driving / driving risk (Gorrod, 2004).

To be more detail to understand the risks that arise and the actual loss in the organization, the organization can use the hierarchy of risk. The hierarchical structure is very dependent on the needs of the organization, by breaking up each line of business organization, eg line marketing, production line, operational lines, where each line has the opportunity to pose a risk. The risk can be avoided or reduced if the root causes of these risks can be identified and

\footnotetext{
The Role of The Internal Audit Management of Enterprise Risk Management
}

Siwidyah Desi Lastianti, Endang Muryani, Mahrus Ali 
managed before disastrous consequences occur (Smith., Merna., Jobling,2006).To achieve these objectives, we need a systematic approach that is risk management.

\section{Risk management}

Risk Managementis described as a process to identify and assess risks, and apply methods to reduce to acceptable limits (Tohidi, 2011). The main activities with respect to the risk is to manage it. In the ISO 31000 risk management process described in figure 3 .

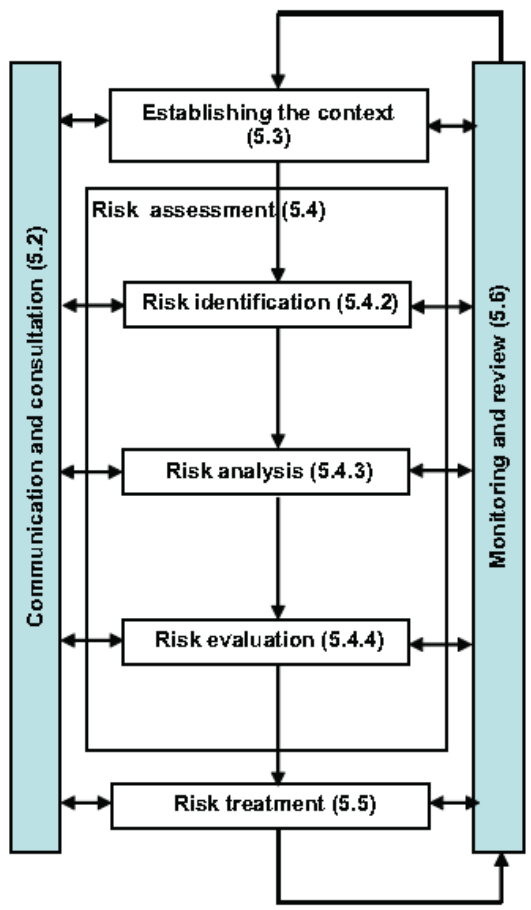

Figure 3- Risk Management Process

Source: ISO 31000

1. Establishingcontext:identify areas of risk that should be considered related to market, product / service, process manufacturing / supply and the area of the external such as suppliers, banks, and so on;

2. Riskassessment: risk assessment consists of (a) Identification Process: The process of identification is done by searching for the cause of the risk, identify, and describe the risks; (b) Analysis Process: The analysis process is a process to understand the nature of risk and to determine the level of risk. Two methods were used to analyze the risk that a risk analysis of qualitative and quantitative risk analysis. Qualitative risk analysis focus on the probability of occurrence of the risk and the consequences if the risk occurs. The most common method in

\footnotetext{
The Role of The Internal Audit Management of Enterprise Risk Management
}

Siwidyah Desi Lastianti, Endang Muryani, Mahrus Ali 
qualitative risk analysis is to $\operatorname{rank}$ (rating)or the scale of probability(probability)and the impact of risk(riskimpact).The determination of the probability scale and the impact of a risk is a subjective thing. This ranking must be agreed by all the project team and should also involve experienced personnel. The determination of this scale includes two ways: (1) determining a scale: scale high - medium - low(high-medium -low);and (2) develop a risk scale ratings which resulted in cost, time, quality and scope. All the risks that have been documented at the time of identification to analyze one by one to determine the probability of occurrence and impact of each risk. Then it will be incorporated into the matrix of probability and risk impact ratings. If there is a risk with a high rating - high, then the risk should receive greater attention. While quantitative risk analysis is done by providing the weighting value. Based on the assessment of each of probability and risk impact will be calculated the value of the risk; (c) Risk Evaluation Process: The purpose of risk assessment is to help make decisions based on the results of risk analysis, about which risks need to get treatment as well as the priority for treatment implementation.

3. Risktreatment: treatment of the risks include the selection of one or more options for modifying risks and implementing these options. Options for treatment of the risks are: (1) the transfer of risk which transfer the risk to another party; (2) to avoid risk is to not do the activities that pose a risk. But keep in mind that avoiding risk can eliminate the opportunity to make a profit for the company; (3) reduce the risk by reducing the chances of risk; (4) accept the risk that by accepting the existing risks but within acceptable limits;

4. Monitoring andreview: a review and monitoring is an integral part of the risk management process to ensure that the control functions effectively and efficiently;

5. Communication and consultationCommunication and consultation is an interactive process to exchange information about risk management with both internal and external stakeholders.

\section{CONCLUSIONS}

The development in the economic field so rapidly cause the intensity of work and business volumes also increased, thus the control of each line of business to be important and will be more difficult. Here, the role of internal audit is needed to assist the management control of each process for each business process that happens must potentially risky. Since 200an risks in business are significantly changed, after the accounting tricks and problems at major companies such as Enron, Worldcom and Parmalat (Benli, Duygu, 2014).

Internal audit was originally only focused on accounting examination, this time the tests associated with risk. Internal audit activities should be able to provide added value to organizations and stakeholders when considering strategies, objectives and risks; working hard on providing a way to develop the process of governance, risk management and control; and objectively provide assurance that relevant. (IIA, 2017).

The Role of The Internal Audit Management of Enterprise Risk Management

Siwidyah Desi Lastianti, Endang Muryani, Mahrus Ali 
In relation to risk management, internal audit duty to contribute to the improvement of the risk management process through a systematic approach, regular, sustainable, risk-based compliance with international standards of internal auditing practices. Internal auditors should also be able to evaluate the effectiveness and efficiency of risk management and encourage sustainable development. Limitations of this study is that the study was only based on a literature review. The results of this study are expected to provide insight for the next study that put more emphasis on experimental research to get more accurate and relevant.

\section{ACKNOWLEDGMENTS}

We thank the institutions Surabaya Merdeka Merdeka University and the University of Sunan Bonang Tuban for the help and support them in improving research. Also we want to show our gratitude to (Siwidyah Desi Lastianti, Endang Muryani and Mahrus Ali) to distribute scholarships and a lesson to us during this study. Also we are very grateful for the comments of fellow lecturer Merdeka University Surabaya.

\section{REFERENCES}

Airmic, Alarm, IRM. (2010). A Structured Approach to Enterprise Risk Management (ERM) and the Requirements of ISO31000.The Public Risk Management Association

Australian Government. ISO / IEC Guide 73 RiskManagement.Australian Transaction Report and Analysis Center. Downloaded on November 22,2014.

Benli, Vahit Ferhan., Duygu Celayir. (2014). Risk Based Internal Auditing And Risk AssessmentProcess.European Center for Research Training and Development UK. www.eajournals.org

Boulescu, M. (2003). FinancialAudit.National Normative Benchmark, Ed. Economica, Bucuresti.

Caratas, Maria Alina., Elene Cerasela Spatariu. (2014). Contemporary Approaches in InternalAudit.Procedia Economics and Finance.

Daniela, Petrascu., Alexandra Tieanu. (2014). The Role of Internal Audit in Fraud Prevention and Detection.Procedia Economics and Finance.

Daniela, Petrascu., Tamas Attila. (2013). Internal Control and Internal Audit versusCoaching.Procedia Economics and Finance.

Hebeish, Ahmed M. Abo. (2016). A Practical Guide To The Art Of InternalAudit. ${ }^{\text {st }}$ Edition. Cognella Academic Publishing, USA.

\footnotetext{
The Role of The Internal Audit Management of Enterprise Risk Management
}

Siwidyah Desi Lastianti, Endang Muryani, Mahrus Ali 
Karagiorgos, Theofanis., George Drogalas, Michail Pazarskis. (2007). Internal Auditing As A Main Tool For Efficient RiskAssessment.Mibes.

Karmudiandri, A. (2014) 'Peranan Audit Internal dalam Manajemen Risiko Bank', Media Bisnis. STIE Trisakti, 6(1), pp. 19-26.

\section{LASTIANTI, S. D. D. (2015) 'KAJIAN MANAJEMEN RISIKO SEBAGAI UPAYA UNTUK MENCAPAI KEBERHASILAN PADA PROYEK KONSTRUKSI BAJA DAN SIPIL DI PT SUPRA SURYA INDONESIA'. UNIVERSITAS AIRLANGGA.}

Lestari, V. N. S. (2018) ‘Analisis Rasio Keuangan Untuk Menilai Kinerja Keuangan Pada Pt. Indofood Sukses Makmur, Tbk, Di Bursa Efek Surabaya (Bes) Periode 1998-2002’. INA-Rxiv.

Syaifudin, A. (2017) 'The Impact of Creativity and Innovation on Increasing Micro Enterprise Income PKL Gading Fajar Sidoarjo. IJEBD (International Journal Of Entrepreneurship And Business Development), 1 (1), 88-98'.

Gorrod, Martin. (2004). Risk Management Systems - Process, Technology andTrends.Palgrave Macmillan.

Munteanu, Victor., Laurentiu Zaharia Dragos. (2013). Current Trends in InternalAudit.Procedia Social and Behavioral Sciences.

Pickett, KH Spencer. (2010). The Internal AuditingHandbook. $3^{\text {rd }}$ Edition. John Wiley and Sons, Ltd., Publication.

Smith, Nigel J., Merna, Tony., Jobling, Paul. (2006). Managing Risk in ConstructionProjects.London: Blackwell Publishing.

Stanciu, Victoria. (2016). Trends and Priorities in InternalAudit.Audit Financiar, XIV, Nr. 9 (141) / 2016, 1003-1008.

The Institute of Internal Auditors. (2004). Internal Auditin's Role In Sections 302 and 404 Of The US Sarbanes-Oxley Act Of2002. www.theiia.org.

The Institute of Internal Auditors. (2017). International Standards for the Professional Practice of Internal Auditing (Standards). www.theiia.org.American Accounting Association.

\footnotetext{
The Role of The Internal Audit Management of Enterprise Risk Management
}

Siwidyah Desi Lastianti, Endang Muryani, Mahrus Ali 